\title{
Öz Yeterlilik ve Örgütsel Özdeşleşmenin Yenilikçi Davranış ve Görev Performansı Üzerindeki Etkisi: Eğitim Sektöründe Bir Araştırma
}

\author{
The Effect of Self-Efficiency and Organizational Identification on Innovative \\ Behavior and Task Performance: A Research in the Education Sector
}

\author{
Salih Zeki İMAMOĞLU ${ }^{1}$, Serhat ERAT ${ }^{2}$, Eda Dilara AYBER ${ }^{3}$
}

\begin{abstract}
Öz
Amaç: $\mathrm{Bu}$ araştırmanın amacı, öz yeterlilik ve örgütsel özdeşleşmenin yenilikçi davranış ve görev performansı üzerindeki etkisini araștırmaktır.

Tasarım/Yöntem: Veri toplama aracı olarak anket yöntem kullanılmıştır. Anket Chen ve arkadaşları (2001) tarafından geliștirilen 8 ifadeli öz-yeterlilik ölçeği, Mael ve Ashforth (1992) tarafindan geliştirilen 6 ifadeli örgütsel özdeşleşme ölçeği, Scott ve Bruce (1994) tarafından geliștirilen 6 ifadeli yenilikçi davranış ölçeği ve Goodman ve Svyantek (1999) tarafından geliştirilen 9 ifadeli görev performansı ölçeğinden yararlanılarak oluşturulmuştur. Araștırma verileri, Kocaeli ili Gebze ilçesindeki eğitim sektöründe çalışan 303 eğitim personelinden toplanmıştır. Toplanan veriler SPSS istatistiksel analiz paket programıla analize tabi tutulmuş ve faktör analizi, korelasyon analizi ve regresyon analizleri ile tes edilmiştir.

Bulgular: Analizler sonucunda öz yeterlilik ve örgütse özdeşleşmenin yenilikçi davranış ve görev performansı üzerinde pozitif yönde anlamlı bir etkisinin olduğu görülmüștür. Araștırma sonucuna göre örgütleri ile özdeşleşen, öz yeterlilikleri yüksek çalışanların gerek yenilikçi davranışları gerekse de görev performanslarında örgüt yararına olumlu sonuçlar sergiledikleri anlaşılmaktadır. Elde edilen bu bulguların yöneticilere ve benzer alanda çalışan araştırmacılara, örgüt çalışanlarının yenilikçi davranışlarını geliştirmeleri ve performanslarını artırmaları hususunda yol göstereceği ve literatüre katkı sağlayacağı düşünülmektedir.
\end{abstract}

Sınırlılıklar: Örneklemin sadece Kocaeli ili Gebze ilçesinden ve eğitim sektöründe çalıșanlardan oluşması bu araştırmanın sinırlılıklarıdır.

Özgünlük/Değer: Öz yeterlilik, örgütsel özdeşleşme, yenilikçi davranış ve görev performansı kavramları ve bu kavramların birbirleriyle olan ilişkileri üzerine yeterince çalışma yapılmış olmasına karşın öz yeterlilik ve örgütsel özdeşleşmenin yenilikç davranış ve görev performansı üzerine etkisini inceleyen çalışmaya literatürde rastlanmamıştır. Bu çalışma ile öz yeterlilik ve örgütsel özdeşleşme gibi pozitif örgütsel davranış kavramlarının yenilikçi davranış ve görev performansı gibi örgütün çıktılarına yönelik değişkenler üzerindeki etkisinin açıklanması amaçlanmakta ve literatürün zenginleşmesine katkı sağlanması hedeflenmektedir. Anahtar Kelimeler: Öz Yeterlilik, Örgütsel Özdeşleşme, Yenilikçi Davranış, Görev Performansı

\section{Abstract}

Purpose: The aim of this study is to investigate the effect of selfefficacy and organizational identification on innovative behavior and task performance.

Design/Methodology: Survey method was used as data collection tool. Questionnaire was created by adopting scales from prior studies, 8-statement self-efficacy scale developed by Chen et al. (2001), 6-statement organizational identification scale developed by Mael and Ashforth (1992), 6-statement innovative behavior scale developed by Scott and Bruce (1994) and 9-statement task performance scale developed by Goodman and Svyantek (1999). The research data were collected from 303 education personnel working in the education sector in Gebze district of Kocaeli province. The collected data were analyzed with the SPSS statistical analysis package program and tested with factor analysis, correlation analysis and regression analysis.

Findings: As a result of the analysis, it was determined that selfefficacy positively and significantly affected innovative behavior, and also organizational identification positively and significantly affected innovative behavior. In addition, it was seen that selfefficacy and organizational identification had a significant positive effect on innovative behavior and task performance. According to the results of the research, it is understood that employees who identify with their organizations and have high self-efficacy display positive behaviors for the benefit of the organization in terms of both their innovative behavior and task performance. It is thought that these findings will guide managers and researchers working in similar fields to develop innovative behaviors of employees in the organization and increase their performance and also contribute to the literature.

Limitations: The limitations of this study are that the sample consists of only Gebze district of Kocaeli province and those working in the education sector.

Originality/Value: Although enough studies have been done on the concepts of self-efficacy, organizational identification, innovative behavior and task performance and the relationships between these concepts, there is no study examining the effect of self-efficacy and organizational identification on innovative behavior and task performance in the literature. This study aims to explain the effect of positive organizational behavior concepts such as self-efficacy and organizational identification on variables such as innovative behavior and task performance and contribute to the enrichment of the literature.

Keywords: Self-Efficacy, Organizational Identification, Innovative Behavior, Task Performance

\footnotetext{
${ }^{1}$ Prof. Dr., Gebze Teknik Üniversitesi, İşletme Fakültesi, Strateji Bilimi Bölümü, imamoglu@gtu.edu.tr, ORCID: 0000-00027160-2370

${ }^{2}$ Doç. Dr., Gebze Teknik Üniversitesi, İşletme Fakültesi, Strateji Bilimi Bölümü, erat@gtu.edu.tr, ORCID: 0000-0003-02278914

${ }^{3}$ Arş. Gör., Gebze Teknik Üniversitesi, İşletme Fakültesi, Strateji Bilimi Bölümü, edayber@gtu.edu.tr, ORCID: 0000-0001$77732-5848$
} 


\section{GİRIŞ}

Rekabetçi ve zorlu piyasalar örgütleri üretim, kâr elde etmek gibi temel gerekliliklerden fazlasını aramaya yönlendirmektedir. Bu sebeple araştırmacılar önemsiz gibi gözüken fakat çoklu etkileri bulunan değişkenleri geliştirmeye yönelmiştir. Bu noktada çalışanın, örgütünü bir adım daha ileri taşımak için kendini yeterli görmesi, yeni yaklaşım ve yöntemlerle örgütün gelişimine katk1 sağlamayı istemesi, örgütle ortak hedeflere sahip olması, örgütün amaçlarını, değer ve inançlarını benimsemesi ve bunun için çaba göstermesi önemlidir. Hem küresel hem de bölgesel rakabette insan kaynağını en verimli ve etkili biçimde kullanarak stratejik rekabette üstünlük sağlamak örgütlerin önemli amaçlarındandır. Bu nedenle pozitif örgütsel davranış kavramları günümüzün rekabetçi iş ortamlarında ilgi çekici araştırma konuları haline gelmiştir. Bu kavramlar üzerine çalışmalar yapılmış olmakla birlikte farklı düzeylerde araştırmalarla gelişim süreçleri devam etmektedir.

Çalışanların işletme içi faaliyetlerinin belirleyicisi bilgi ve becerilerinden ziyade öz yeterlilik algıları olarak görülmektedir (Bandura, 1995). Bilgi ve beceriler potansiyeli oluştururken o potansiyeli gerçekleştirmeye yönelik çabayı tetikleyecek olan öz yeterlilik algısı olduğundan bireyin gelişime yönelik çabasını ve faaliyetlerini etkileyecektir (Luszczynska vd., 2005). Benzer şekilde, çalışanların örgütleriyle özdeşleşmeleri ile çalıştıkları örgütün parçası gibi hissedeceklerine ve örgütün başarısı için daha fazla efor sarf edeceklerine ve performans göstereceklerine dikkat çekilmektedir (Miller vd., 2000). Bunun yanısıra kendisini yeterli gören bireyler önerilerini dile getirmek, farklı yaklaşımlar geliştirmek ve risk almak konusunda daha cesur davranacaklardır. Böylece yenilikçi girişimlerde bulunma ihtimalleri de artacaktır. Yenilikçilik, örgütlerin büyümesini sağlayan en önemli faktörlerden biridir ve çalışanların yenilikçi davranışları, örgüt yenilikçiliğinin ve örgüt başarısının önemli bir kaynağıdır (Ng \& Lucianetti, 2016).

$\mathrm{Bu}$ çalışma yenilikçi davranışları teşvik eden öz yeterlilik ve örgütsel özdeşleşme gibi içsel denetim mekanizmalarını ele almaktadır. Çalışanın kendisini örgüt ile bir bütün olarak ele alması, örgüt değer yargılarını ve inançlarını kendi değer yargıları ve inançları gibi benimsemesi örgütün faydasına olacak yeni fikir ve yaklaşımları geliştirmek ve uygulamak konusunda daha girişken ve özverili olmasını sağlayacaktır. Bu yöndeki faaliyetlerin tamamı yenilikçiliğe olumlu etkilerde bulunacak ve böylece yeni yaklaşımların uygulanması örgütsel faaliyetlerin artmasına sebep olacaktır. Yenilikçi fikir ve yaklaşımları geliştiren, uygulama imkânı bulan ve bu faaliyetleri takdirle karşılanan çalışanların örgütlerinde kendilerini daha fazla geliştirmeleri için imkanlara sahip olmaları ve bu faaliyetlerinin takdirle karşılanmasının bir sonucu olarak örgütlerine daha bağlı ve birlikte gelişimi gözeten konumda olmaları daha olasıdır (Dirani, 2009; Tang vd., 2020). Örgütlerin en önemli değişkenlerinden biri olan çalışanların faaliyet ve yaklaşımları her geçen gün fark yaratıcı hale gelmektedir. Mümkün olan en az insan kaynağı ile en verimli ve aynı zamanda etkili sonuçlara ulaşmak yeterliliklerin ötesinde faaliyetler göstermek örgütler için belirleyiciliğini arttırmaktadır. Bu çalışma ile öz yeterlilik ve örgütsel özdeşleşme gibi pozitif örgütsel davranış kavramlarının yenilikçi davranış ve görev performansı gibi örgütün çıktılarına yönelik değişkenler üzerindeki etkisinin açıklanması amaçlanmakta ve literatürün zenginleşmesine katk1 sağlaması hedeflenmektedir. Bu çerçevede öz yeterlilik, örgütsel özdeşleşme, yenilikçi davranış ve görev performansı ile ilgili literatür gözden geçirilmiş, araştırmanın teorik altyapısı kurgulanmış, araştırmanın yöntemi anlatılmış, verilerin analizi ve elde edilen sonuçlara dayalı bir değerlendirme yapılmıştır.

\section{TEORİK ÇERÇEVE}

\section{1. Öz Yeterlilik}

Belli bir amaç doğrultusunda gerçekleştirilen insan faaliyetlerinde birçok unsur etkilidir. Albert Bandura, bireylerin belirli bir davranışı sergilemesi için ortaya koyacağı çabanın miktarını belirleyen faktörlerden birinin bireyin yeterliliğine olan inancını ifade eden öz-yeterlilik inanc1 olduğunu ileri sürmüştür ve öz yeterlilik kavramı ilk kez "Sosyal Bilişsel Teori'nin" ana unsurlarından biri olarak tanıtılmıştır (Bandura, 1977; Bandura, 1982). İlerleyen çalışmalarında Bandura öz yeterlilik kavramını "bireylerin olası durumlar ile başa çıkabilmek için gerekli olan eylemleri ne kadar iyi yapabildiklerine ilişkin yargıları" (Bandura, 1982) ve "kişinin kendisinden beklenen durumları yönetmesini sağlayacak yeteneklere olan inancı" (Bandura, 1995) şeklinde tanımlamıştır. Öz yeterlilik kavramında tanımdan da hareketle dikkat edilmesi gereken husus tamamı ile kişinin algısına bağlı 
olmasıdır. Öz yeterlilik algısı bireyin bir eylemi veya faaliyeti gerçekleştirmeye yönelik yeterliliklerine ilişkin kişisel değerlendirmesi, yarg1 ve inançları doğrultusunda belirlenmektedir. Bireyin imkân ve kapasitesi hakkındaki kendi algı, inanç ve varsayımlarından oluşmaktadır. Kavram literatürde "kiş̧ilerin, talep edilen zor görevler ve kendi uygulamaları üzerinde kontrol tesis edebilme yeteneklerine olan inancı" olarak da tanımlanmaktadır (Luszczynska vd., 2005).

Öz-yeterliği düşük olan kişilerin düşük benlik saygısına sahip oldukları, başarıları ve kişisel gelişimleri hakkında karamsar düşünceler barındırdıkaları ve bu sebeple sıkıntı, anksiyete, çaresizlik, tükenmişlik ve depresyon gibi olumsuz duygular ile baş etmek durumunda kaldıkları tespit edilmiştir (Bandura, 1997; Evers vd., 2002; Cieslak vd., 2016). Öz yeterliliğin arkasında yatan bu dinamikler sebebiyle bireyler bir faaliyet için gerekli yetkinliklere sahip olmalarına rağmen öz yeterlilik inançlarının düşük olması sebebiyle faaliyetlerden kaçınabilir veya potansiyellerini gerçekleştirme eğiliminde olmayabilirler. Öz yeterlik, etkili problem çözmeyi ve ardından olumlu duyguların artmasını sağlamakla birlikte bireylerin stres değerlendirmelerini de etkilemektedir (Luszczynska vd., 2005; Newman vd., 2019). Yapılan çalışmalar ile yüksek öz yeterlilik algısının karar verme kalitesi, bilgi işleme, problem çözme, performans, iyimserlik, öz düzenleme, öz saygı ve geleceğe yönelim ile olumlu yönde ilişkili olduğu ortaya konmuştur (Bandura, 1997; Luszczynska vd., 2005). Güçlü öz yeterliliğe sahip bireyler, engellerin üstesinden gelebileceklerini bilirler ve bu nedenle stresli durumların ve zorlukların üstesinden gelme yetenekleriyle ilgili kendilerinden şüphe duymazlar (Luszczynska vd., 2005).

\section{2. Örgütsel Özdeșleșme}

Özdeşleşme, bir grubun birliği veya bir gruba ait olma algısıdır (Ashforth \& Mael, 1989) ve kişinin kendi kendisini sınıflandırmasından kaynaklanır (Dutton vd., 1994). Grubun başarı ve başarısızlıkları özdeşleşme nedeniyle birey tarafından da özdeşleşmenin yoğunluğuna göre değişen şekillerde dolaylı ya da doğrudan deneyimlenir (Ashforth \& Mael, 1989). Bir çalışanın örgütün ayırt edici, merkezi ve kalıcı nitelikleri hakkındaki inançları, üyenin örgütle özdeşleşme derecesini etkileyen güçlü bir imaj görevi görebilir. Örgütsel özdeşleşme araştırmacılar ve uygulamacılar tarafından, bireyin örgütle istenen bağı olarak kabul edilmiştir (Ashforth \& Mael, 1989; Dutton vd., 1994; Carmeli vd., 2007). Bazı araştırmacılar bir üye ile örgütü arasındaki değer uyumu olarak örgütsel özdeşleşmeye odaklanırken (Hall vd., 1970; Lee, 1971; Hall \& Schneider, 1972), bazıları da bilişsel bağlantıya odaklanmıştır (Ashforth \& Mael, 1989; Dutton vd., 1994). Ashforth ve Mael (1989) özdeşleşmesi yüksek çalışanlara sahip örgütlerin, yeni gelen kişinin örgütü somutlaştırmasını, ona sadık ve bağlı hissetmesini sağladığını, ayrıca örgütsel değerlerin ve inançların içselleştirilmesini de kolaylaştırdığını ortaya koymuştur.

Araştırmalarda bir örgütün diğer örgütlerle karşılaştırılması durumunda, çalışan tarafından daha farklı algılanıyorsa, örgüt kimliği çalışan tarafından çekici olarak algılanıyorsa, örgüt prestiji çalışan tarafından yüksek algılanıyorsa örgütsel özdeşleşme potansiyelinin arttığı ortaya konmuştur (Asford \& Mael, 1989; He \& Brown, 2013). Bu sonuçlar insanların kişilerarası bağlamlarda kendi ayırt ediciliğini vurgulamaya çalıştıkları varsayımını doğrular niteliktedir. Ayrıca hem Asford ve Mael'in (1989) hem de Dutton vd.'nin (1994) çalışmaları örgüt dışından gelen tehditlerin de çalışanın parçası olduğu örgüt ile özdeşleşmesini arttırdığını ortaya koymuştur. İnsanların kendileri ile ilgili bilgilerle kendileri ile alakasız bilgilerden farklı bir şekilde ilgilendikleri ve işledikleri savı (Markus \& Wurf, 1987) bireyin kendiyle ilgili bilgileri tanıma ve geri getirmesinin göreli kolaylığı, kendisiyle eşleşen örgütsel kimlikleri daha çekici kılacağı yönündeki düşünceyi destekler niteliktedir. Örgütleriyle yüksek oranda özdeşleşmiş çalışanlar, grup normlarını ve değerlerini kendi öz kavrayışlarına dahil ettikleri için iş sözleşmeleri veya kontrol mekanizmaları tarafından resmen zorlanmasalar bile gruplarının normları ve değerleri adına düşünerek hareket ederler (Gautam vd., 2004). Örgütün çalışanlarının örgütsel özdeşlemesini arttırmak istemesinin arkasında çalışan performansına ve örgüte yapacağı bu olumlu etkiler bulunmaktadır.

\subsection{Yenilikçi Davranış}

Piyasalarda rekabetin yoğunlaştı̆̆1 ve küreselleşmenin arttığ1 günümüz şartlarında örgütler sadece yeniliklere ayak uydurmak zorunda kalmayıp yenilikleri yaratan tarafta olmak için de çabalamaktadır. Yeniliği yaratan tarafta olan firmalar rekabette fark yaratırken, gelişime adapte 
olabilen firmalar varlıklarını sürdürebilmektedir. Yenilikçilik, açık fikirlilik ile başlamakta ve fikirlerin faaliyetlere dönüşmesi ile sürdürülmektedir (Woodman vd., 1993). Yenilikçi davranış, fikirlerin doğuşu ve uygulanması aşamalarından oluşan çok katmanlı bir süreç olarak ele alınmıştır (Scott \& Bruce, 1994; Axtell vd., 2000; Bani-Melhem vd., 2018). Literatürde yaratıc1lık yenilikçiliğin kaynağı, yenilikçilik de yaratıcı fikirlerin uygulanması olarak tanımlanabilmektedir (Pirola-Merlo \& Mann, 2004; West, 2002). Bu tanımlardan hareketle yenilikçi davranış, çalışanın bilinçli olarak ürünlere, süreçlere, prosedürlere yönelik yeni fikirlerini ve ilhamlarını kendi biriminde veya örgütünde uygulaması veya faaliyetlerine yansitması olarak ifade edilebilir.

Yenilikçi çalışanlar, yeni fikirler üretmek ve mevcut süreçleri iyileştirmek için çaba harcar, bilgi toplar ve güncel gelişmeleri takip eder (Riaz vd., 2018). Yeni teknolojileri arama ve keşfetme, amaçlara ulaşmayı sağlayacak yeni yollar üretme, yeni çalışma yöntemleri geliştirme, yeni kaynaklar araştırma veya üretme davranışları yenilikçi davranış örnekleri olarak sayılabilir (Yuan \& Woodman, 2010). Sürpriz durumlara ve alışılmadık şartlara uyum sağlayabilmek için yenilikçi eylemlere ihtiyaç duyulmaktadır (Janssen, 2003). Çalışanlar tarafından sunulan yeni ve yararlı yaratıcı fikirlerin başarılı bir şekilde uygulanması örgütlerin rekabet avantajı kazanmasında önemli bir faktördür (Michael vd., 2011; Omri, 2015). Yenilik, bir firmanın rekabet avantajı ve uzun vadeli hayatta kalması için hayati öneme sahip olmuş (Greenhalgh vd., 2005; Thurlings vd., 2015) ve bu nedenle, değişimi sağlayan veya temsil eden yenilikçi konumundadır.

\subsection{Görev Performansı}

Çalışanların performansı, organizasyonun etkililiğini ve başarısını geliştirmenin temel taşıdır. Son yıllarda, artan rekabet baskıları karşısında kurumların sürekli olarak insan kaynaklarını optimize etmeye çalışmasıyla performans yönetimi ön plana çıkmaktadır. Araştırmacılar arasında performansın çalışma organizasyonlarında önemli bir değişken olduğu konusunda genel bir fikir birliği olduğu söylenebilir. Literatürde performansın çok boyutlu bir yapıda olduğu kabul görse de uygulamada genellikle görev performansı ve bağlamsal performans olarak iki boyutta incelenmektedir (Borman \& Motowidlo, 1997; Befort \& Hattrup, 2003; Jawahar \& Carr, 2007).

Görev performansı, belirli bir işle ilgili görev ve sorumlulukların yerine getirilmesi olarak tanımlanmaktadır. Görev performansı, örgütün teknik ya da teknolojik sürecinin bir bölümünü doğrudan uygulayarak ya da ihtiyaç duyulan malzeme veya hizmetleri sağlayarak katkıda bulunan faaliyetlerin gerçekleştirilmesi olarak tanımlanmıştır (Borman \& Motowidlo, 1997). Görev performansı, iş tanımları kapsamında temel faaliyetlerin yerine getirilmesine yönelik performans olup işin değişmeyen görevleri, gerçekleştirilmesi gereken temel sorumlulukları ve bu sorumluluklara ilişkin faaliyetleri ifade eder (Jawahar \& Carr, 2007; Peng vd., 2020). En basit haliyle örgütün hedef ve amaçlarına uygun olan eylemlerin gerçekleştirilmesine yönelik gösterilen performanstır (Suliman, 2001).

\section{HIPOTEZ GELIŞTİRME}

\section{1. Öz Yeterlilik Algısı ve Yenilikçi Davranış İlişkisi}

Bireylerin karşılarına çıkabilecek olası problemlerle baş edebileceklerine inanıyor olmaları örgütsel alanda yenilikleri başlatma konusunda daha girişken olacakları beklentisini oluşturmaktadır. Literatür incelendiğinde öz-yeterliği yüksek olan çalışanların işyerinde yüksek düzeyde yenilikçi davranış sergilediği görülmektedir (Hsiao vd., 2011; Michael vd., 2011; Yu \& Chen, 2016). Hsiao vd. (2011) çalışmaları ile öz yeterliği daha yüksek olan çalışanların daha yenilikçi davranışlar sergilediğini ortaya koymuştur. Kendilerinden emin olan çalışanlar yenilikçi görevler uyguladıklarında başarısızlıklar ve belirsizliklerle başarılı bir şekilde baş edebilmektedir (Seligman \& Csıkszentmıhalyı, 2000). Ayrıca öz-yeterlik inançlarındaki artışlar zaman içinde fikir üretme, yayma ve uygulamada da artışları teşvik etmektedir (Chen vd., 2016; Fuchs vd., 2019). Yaratıcı öz-yeterliğin yenilikçi davranış üzerindeki olumlu etkisi olduğu ve bilgi paylaşımının yüksek olduğu çalışma ortamlarında, bilgi paylaşımı düşük çalışma ortamlarına göre daha büyük olduğu ortaya konmuştur (Teng vd., 2019). Ayrıca Mielniczuk ve Laguna (2020) görevlerini başarılı bir şekilde yerine getirme yeteneklerine inananların işlerine karşı daha fazla heves ve rahatlık yaşadıklarını ve bu olumlu etkilerin daha sonra yenilikçi davranışlara dönüştügünü ortaya koymuşlardır. Bandura (1995) sosyal reformcuların sosyal değişimi ortaya koymak için gerekli olan kolektif çabayı harekete geçirebileceklerine yoğun biçimde 
inandıklarını belirtmiş ve başarılarını bu şekilde açıklamıştır. Ng ve Lucianetti (2016) çalışmalarıyla yaratıcı öz-yeterlilik ile fikir üretme, yaratma ve uygulama arasında pozitif yönlü ilişki olduğunu ortaya koymuştur. Öz yeterliği yüksek bireylerin daha yenilikçi davranış sergileyecekleri öngörüsünden hareketle aşağıdaki hipotez oluşturulmuştur.

Hipotez 1: Öz yeterlilik algısı yenilikçi davranışı pozitif yönde etkiler.

\section{2. Örgütsel Özdeşleşme ve Yenilikçi Davranış İliş̧kisi}

Literatür, çalışanların örgüt tarafından kendilerine değer verildiğine ve önemsendiklerine ilişkin genel algısının yenilikçilik ile olumlu bir şekilde ilişkili olduğunu göstermiştir (Eisenberger vd., 1990). Yapılan araştırmaların büyük bir bölümü dolaylı da olsa örgütsel özdeşleşmenin yenilikçiliğe olumlu yönde bir etkisi olduğunu göstermektedir (Xenikou, 2017). Fakat bu alandaki araştırmalar oldukça sınırlıdır. Geçmişte yapılan çalışmalar bilişsel özdeşleşmeden ziyade duygusal özdeşleşmenin yenilikçilik üzerinde etkisi olduğunu göstermiştir. Özdeşleşmenin duygusal dinamikleri aynı zamanda insanların belirli bireyler veya gruplar için anlamlı kabul edilen temel değerler ve inançlar gibi göze çarpan örgütsel özelliklere bağlanması ile ilişkili bulunmuştur (Huy, 1999). Çalışanlar özdeşleşme sebebiyle çabalarını problem çözmek için yenilik yapmak, farklı yaklaşımlarda bulunmak gibi faaliyetlere yönlendirebilir. Literatürde çalışanların çalışma grupları ve örgütleri etrafinda oluşturdukları sosyal kimliklerin, çalışanların görev dışı davranışlarda bulunup bulunmadığıyla yakından ilişkili olduğunu gösteren çalışmalar da bulunmaktadır (Blader \& Tyler, 2009). Bu sonuçlardan hareketle aşağıdaki hipotez oluşturulmuştur.

Hipotez 2: Örgütsel özdeşleşme yenilikçi davranışı pozitif yönde etkiler.

\subsection{Yenilikçi Davranış ve Görev Performansı İlişkisi}

Suliman (2001) araştırmasının bir sonucu olarak çalışma şevkinin ve yeniliğe hazır olmanın performansta önemli faktörler olduğu ve göz ard1 edilmemesi gerektiği yönünde önerilerde bulunmuştur. Yenilikçiliğin performansa olumlu etkisine yönelik göstergeler devam eden literatürde görgül çalışmalar ile kendisine yer bulmuştur (Aryee vd., 2012; Moreira \& Silva, 2013). Çalışan yenilikçi davranışı görev performansına bağlayan araştırmaların sayısı az olsa da yenilikçi davranış ve görev performansı arasında olumlu ilişki bulan çalışmalar mevcuttur (Janssen \& Van Yperen, 2004; Gilson vd., 2005; Gong vd., 2009; Aryee vd., 2012; Tang vd., 2020). Çalışanların karşılaştıkları sorunları çözmek için yeni fikirler keşfetmeyi ve geliştirmeyi öğrenmeye daha istekli olmaları bu konuda harcadıkları çaba dolayısıyla da görev performansını artırmaları olası görülmektedir (Amabile vd., 2005; Walumbwa vd., 2009; Tang vd., 2020). Açıklanan dayanaklardan hareketle aşağıdaki hipotez oluşturulmuştur.

Hipotez 3: Yenilikçi davranış görev performansını pozitif yönde etkiler.

\section{4. Öz Yeterlilik ve Görev Performansı İlişkisi}

Öz yeterlilik ile performans ilişkisi uzun süredir ilgi çekici bir çalışma alanı olarak incelenmektedir. Öz yeterliliğin performans üzerinde hem dolaylı hem de doğrudan etkisini gösteren birçok çalışma yapılmıştır (Locke vd., 1984; Barling \& Abel, 1983; Stajkovic \& Luthans, 1998; Fattah vd., 2017; Kim \& Koo, 2017). Öz yeterliliği zedeleyen faktörler dolayısı ile görev performansında olumsuz yönde bir etki meydana geldiğini ortaya koymuştur. Çalışmalar zorlu görevler hakkında özyeterlik inançlarını ve aynı zamanda çalışan bağlılığını arttırmanın görev performansını iyileştirmeye çalışırken ele alınması gereken kritik faktörler olduğunu göstermektedir (Carter vd., 2018). İş ortamında öz yeterlilik ile performans ilişkisini baz alan bir meta analiz çalışmasında öz yeterlik ile görev performansı arasında pozitif bir ilişki olduğu ortaya konmuştur. Ayrıca görev karmaşıklığının bu ilişkiyi zayıflatıcı bir etkiye sahip olduğu belirtilmiştir. Öz yeterlilik kavramı özellikle bireyin harekete geçip geçmeyeceğine yönelik belirleyici konumda olduğundan görev performansına ilişkin olumlu etkisi öngörülebilirdir. Bu öngörüden hareketle aşağıdaki hipotez oluşturulmuştur.

Hipotez 4: Öz yeterlilik görev performansını pozitif yönde etkiler. 


\section{5. Örgütsel Özdeşleşme ve Görev Performansı İlişkisi}

Örgütün önemli değişkenlerinden biri olan örgütsel özdeşleşme pek çok değişkene pozitif etkide bulunmaktadır. Çalışanların en belirgin çıktılardan olan performansa olumlu yönde katkıda bulunacağ pek çok çalışmada öngörülmüştür. Örgütle güçlü bir bağ kuramayan çalışanların örgütsel özdeşleşmesi zayıflayabilir ve bu da performans gibi işle ilgili sonuçların engellenmesine sebep olabilir (Li vd., 2016). Örgütsel özdeşleşme, örgütün özelliklerinin ve başarısının bir bireyin benlik kavramına dahil edildiği bir bağlılığı temsil ettiğinden, yüksek düzeyde örgütsel özdeşleşmeye sahip çalışanlar iş rollerini tanımlama ve kuruluşlarına fayda sağlayan faaliyetlere katılma konusunda daha az kısıtlı hisseder ve daha faaldir (Christ vd., 2003; Liu vd., 2020). Örgütsel özdeşleşme düzeyi düşük olanlara göre örgütsel özdeşleşme düzeyi yüksek olanların daha fazla katkı ve çaba gösterdikleri yapılan araştırmalarla ortaya konmuştur (Van Knippenberg \& Van Schie, 2000; Riketta, 2005). Kendini örgüte ait ve örgütle aynı amaca hizmet eder konumda gören, örgütün başarı ve başarısızlıklarını paylaşan çalışanlar daha fazla çaba göstermeye gönüllü olabilir ve bu durum da onların görev performanslarını iyileştirmelerini sağlayabilir (Sverke vd., 2019). Literatürde pek çok çalışma örgütsel özdeşleşme ile görev performansı arasında hem dolaylı hem de doğrudan etkileri gösteren sonuçlara ulaşmıştır (Carmeli vd., 2007; Liu vd., 2011; Walumbwa vd., 2011; Lu vd., 2016; Liu vd., 2020). Açıklanan öngörülerden hareketle aşağıdaki hipotez oluşturulmuştur.

Hipotez 5: Örgütsel özdeşleşme görev performansını pozitif yönde etkiler.

Öz yeterlilik, örgütsel özdeşleşme, yenilikçi davranış ve görev performansı arasındaki ilişkiyle ilgili geliştirilen hipotezlere göre oluşturulan araştırma modeli Şekil 1'de verilmektedir.

Şekil 1: Araştırmanın Modeli ve Hipotezleri

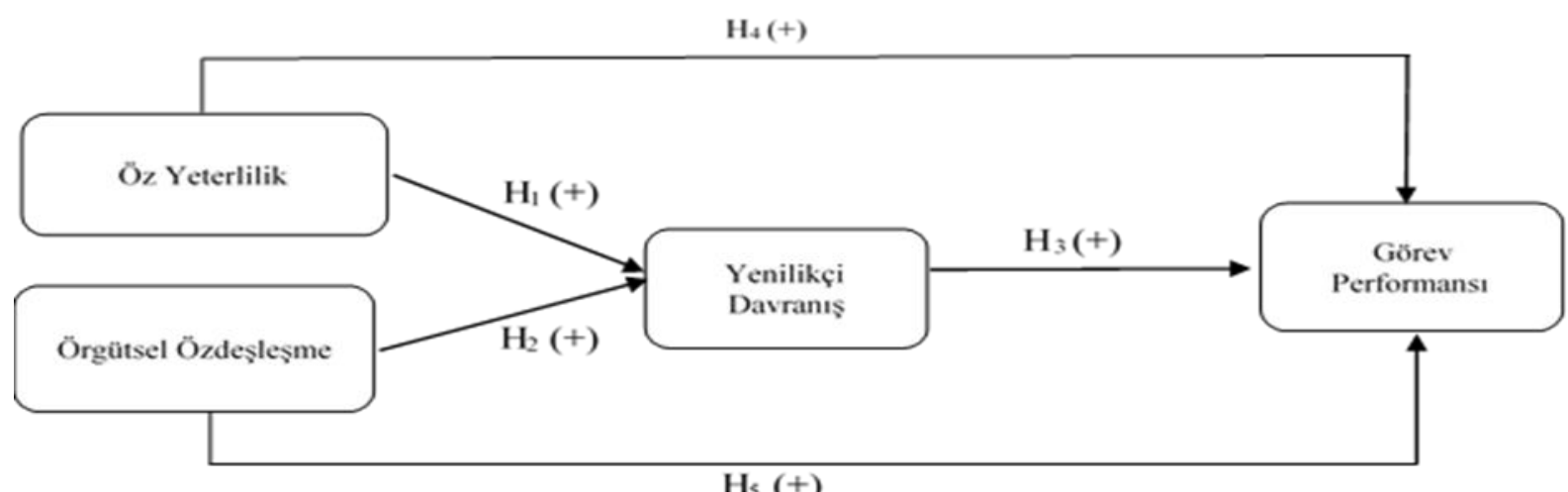

\section{METODOLOJi}

\section{1. Örneklem ve Veri Toplama Süreci}

Öz yeterlilik ve örgütsel özdeşleşmenin, yenilikçilik davranışı ve görev performansı üzerindeki etkisini değerlendirmek için bir saha araştırması gerçekleştirilmiştir. Araştırmanın hipotezlerini test etmek için gereken veriler, Kocaeli ili Gebze ilçesinde Milli Eğitime bağlı okullarda görev yapan çalışanlardan (Gebze'de toplam görev yapan öğretmen sayıs1 4.593 kişidir) (Gebze Milli Eğitim Müdürlüğü, 2019) kolayda örnekleme ile seçilen bir örneklemden hareketle anket yöntemiyle toplanmıştır. Örneklem büyüklügü ile ilgili olarak, Floyd ve Widaman'a (1995) göre 300-400 kişi yeterli iken Tabachnick ve Fidell'e (2007) göre ise bu sayının yapılacak analizlerde yeterli olabilmesi için en az 300 örneklem sayısına ulaşılması gerekmektedir. Literatürden elde edilen ölçeklere dayanarak oluşturulan bir anket formu, ulaşılan 313 personele dağıtılmış olup bunlardan 306 adedi geri dönmüş, 3 adedi doldurma hatası nedeniyle araştırmaya dahil edilmemiş ve nihayetinde 303 adet anket değerlendirmeye alınmıştır. Araştırmada yer alan örneklem sayısının yeterli olduğu görülmektedir.

Anket formunun ilk bölümünde cevaplayıcıların demografik özelliklerini belirlemeye yönelik sorular yer almaktadır. İkinci bölümde; öz yeterlilik algılarını ölçmek için Chen vd. (2001) tarafından geliştirilen 8 ifadeli öz-yeterlilik ölçeği, örgütsel özdeşleşme algısını ölçmeye yönelik Mael ve 
Ashforth (1992) tarafından geliştirilen 6 ifadeli örgütsel özdeşleşme ölçeği, yenilikçi davranışı ölçmek için, Scott ve Bruce (1994) tarafindan geliştirilen 6 ifadeli yenilikçi davranış ölçeği ve son olarak görev performansını ölçmek için, Goodman ve Svyantek'in (1999) tarafindan geliştirilen 9 ifadeden oluşan ölçek kullanılmıştır. Tüm ölçekler "1. Kesinlikle katılmıyorum” dan "5. Kesinlikle Katılıyorum" şeklinde derecelendirilen 5'li Likert ölçeği kullanılarak ölçülmüştür.

\subsection{Araştırma Etiği}

Öz yeterlilik ve örgütsel özdeşleşmenin yenilikçi davranış ve görev performansı üzerindeki etkisi'nin belirlenmesine yönelik yapılan araştırmada veri toplama aracı olarak anket kullanılmıştır. Bu çalışmada anket uygulaması için Gebze Teknik Üniversitesi Etik Kurulu'ndan 28/01/2021 tarihli ve 2021/05 nolu toplantısında 05/01 sıra sayılı kararı ile izin alınmıştır.

\subsection{Verilerin Analizi ve Bulgular}

Araştırmadaki verilerin analizi için SPSS paket programı kullanılmıştır. Bu amaçla öncelikle araştırmaya katılan 303 cevaplayıcının sosyo-demografik özelliklere ilişkin sorulara verdiği yanıtların frekans dağılımı yapılmıştır. Araştırmaya katılan çalışanların \%72'si erkek, \%28'i ise kadın çalışanlardır. Katılımcıların \%28'i 23-30 yaş, \%49'u 31-42 yaş ve \%23'ü ise 43 yaş ve üzeri gruptadır. Ankete katılanların mesleki deneyimlerinin dağılımına bakıldığında, bunların \%18'inin 1-5 yıl, \%36'sının 6-10 y11, \%30'unun 11-15 y11, \%12'sinin 16-20 y1l ve \%4'ünün ise 21 yıl ve üzerinde mesleki deneyime sahip oldukları görülmektedir. Ayrıca araştırmaya katılanların \%5,6'sı müdür, $\% 8,6$ 'sı müdür yardımcısı ve \%85,8'i ise öğretmen olarak görev yapmaktadır.

Bir sonraki adımda, öz yeterlilik, örgütsel özdeşleşme, yenilikçi davranış ve görev performansını ölçmeye yönelik sorulara verilen yanıtlar üzerinde keşifsel faktör analizi gerçekleştirilmiştir. Yapılan ön değerlendirmede verilerin faktör analizine uygun olduğu belirlenmiştir $(\mathrm{KMO}=0,918$ ve Bartlett'in küresellik testi $\mathrm{p}<0,001)$. Varimax döndürme işlemi kullanılarak yapılan temel bileşenler analizi sonucunda araştırma modelindeki değiş̧kenleri oluşturan 29 soru, toplam varayansın \%62,49'unu açıklayan 4 faktöre ayrılmıştır. Tablo 1'de faktör analizi sonucunda ortaya çıkan faktör yükleri görülmektedir. Ortaya çıkan faktörler, öz yeterlilik, örgütsel özdeşleşme, yenilikçi davranış ve görev performansıdır.

Tablo 1: Kullanılan Ölçeklere İlişkin Faktör Analizi Sonuçları

\begin{tabular}{|c|c|}
\hline & Faktör Yükü \\
\hline \multicolumn{2}{|l|}{ Öz Yeterlilik } \\
\hline Kendim için belirlediğim hedeflerin çoğuna ulaşırım. & 0,796 \\
\hline Zor görevlerle karşılaştığımda, bunları başaracağımdan eminim. & 0,781 \\
\hline Genel olarak, benim için önemli olan sonuçları elde edebildiğimi düşünüyorum. & 0,699 \\
\hline Yapmaya karar verdiğim her şeyi başarabileceğime inanıyorum. & 0,720 \\
\hline Başarılı bir şekilde birçok zorluğun üstesinden gelirim & 0,675 \\
\hline Birçok farklı görevlerde etkili bir şekilde çalışabildiğime eminim. & 0,581 \\
\hline Başkaları ile karşılaştırıldığında, çoğu görevleri çok iyi bir şekilde yapabilirim. & 0,692 \\
\hline İşler zor olsa bile, oldukça iyi performans gösterebilirim. & 0,702 \\
\hline \multicolumn{2}{|l|}{ Örgütsel Özdeșleşme } \\
\hline Biri çalıştığım okulu eleştirirse bunu kişisel hakaret olarak algılarım. & 0,742 \\
\hline İnsanların çalıştığım okul hakkındaki düşünceleri benim için çok önemlidir. & 0,735 \\
\hline Çalıştığım okul hakkında konuşurken genellikle "biz" ifadesini kullanırım. & 0,807 \\
\hline Çalıştığım okulun başarısını kendi başarım gibi hissederim. & 0,617 \\
\hline Biri çalıştı̆̆ım okulu övdüğünde bunu kendime iltifat edilmiş gibi hissederim. & 0,713 \\
\hline Medyada çalıştı̆̆ım okula yönelik bir eleştiri olursa bundan rahatsızlık duyarım. & 0,780 \\
\hline \multicolumn{2}{|l|}{ Yenilikçi Davranış } \\
\hline Yeni teknolojiler, süreçler, teknikler araştırırım ve fikirler üretirim. & 0,775 \\
\hline Yaratıcı fikirler üretirim. & 0,794 \\
\hline Diğer çalışanların fikirlerini destekler ve onları cesaretlendiririm. & 0,791 \\
\hline Yeni fikirler için kaynaklar araştırır ve tahsis ederim. & 0,692 \\
\hline Yeni fikirlerin uygulanması için planları ve faaliyet takvimlerini geliştiririm. & 0,704 \\
\hline Yenilikçiyim. & 0,717 \\
\hline
\end{tabular}


Tablo 1 (Devamı): Kullanılan Ölçeklere İlişkin Faktör Analizi Sonuçları

\begin{tabular}{lc}
\hline & Faktör Yükü \\
\hline Görev Performansı & 0,645 \\
\hline İsimin bütün amaçlarına ulaşırım. & 0,820 \\
Bölümümden sorumlu amirin, performans kriterlerine uygunum ve uygun çalışırım. & 0,821 \\
İşle ilgili bütün görevlerde, mesleğimin gerektirdiği uzmanlıkla iş görürüm. & 0,882 \\
İşimin gerektirdiği bütün görevleri yerine getiririm. & 0,878 \\
Verilen görevden daha fazla sorumluluk üstlenebilirim. & 0,867 \\
Daha üst bir pozisyon için uygun görünmekteyim. & 0,802 \\
İşin kapsadığı bütün alanlarda yetenekliyim ve bütün görevlerle profesyonel bir şekilde başa çıkarım. & 0,829 \\
Verilen görevleri istenilen şekilde yerine getirerek, işin genelinde iyi bir performans sergilerim. & 0,746 \\
İşimin amaçlarına ulaşmasını planlar ve verilen görevi, tamamlanması gereken zamanda tamamlarım. & \\
\hline Açıklanan Toplam Varyans \%62,49 & \\
\hline
\end{tabular}

Oluşturulan kompozit değişkenlere ilişkin tanımlayıcı istatistikler, değişkenler arası korelasyonlara ilişkin bilgiler ve ölçeklerin güvenilirliklerini değerlendirmek için hesaplanan Cronbach Alpha güvenilirlik katsayıları Tablo 2'de yer almaktadır. Ölçeklerin güvenilirlik değerlerinin 0,81 ile 0,94 arasında değişdiği görülmektedir. Araştırmanın değişkenlerine ilişkin korelasyon analizi sonucunda; örgütsel özdeşleşme ile öz yeterlilik arasında, yenilikçilik ve öz yeterlilik arasında, örgütsel özdeşleşme ve yenilikçilik arasında, örgütsel özdeşleşme ve görev performansı arasında ve yenilikçilik ve görev performansı arasında 0,01 anlamlılık düzeyinde ve istatistiksel olarak anlamlı pozitif ilişki ortaya konmuştur. Ayrıca değişkenlerin normal dağılım gösterip göstermedikleri ile ilgili olarak çarpıklık ve basıklık değerlerine bakılmıştır. Normalde çarpıklık ve basıklıkla ilgili elde edilen değerlerinin \%5 güven aralığında $-2,58$ ile $+2.58, \% 1$ güven aralığı için ise, -1.96 ile +1,96 istatistik değer aralığında olması beklenir (Liu vd., 2005). Tablo 2'de görüldüğü üzere, değişkenlerin normal dağılım gösterdikleri söylenebilir.

Tablo 2: Değişkenler Arasındaki Korelasyonlar ve Güvenirlik Analizi Sonuçları

\begin{tabular}{llcccccccc}
\hline & \multicolumn{1}{c}{ Ortalama } & Çarpıklık Basıklık & Standart Sapma & $\mathbf{1}$ & $\mathbf{2}$ & $\mathbf{3}$ & $\mathbf{4}$ \\
\hline $\mathbf{1}$ & Öz Yeterlilik & 4,01 & $-0,328$ & 1,596 & 0,58 & - & & & \\
\hline $\mathbf{2}$ & Örgütsel Özdeşleşme & 3,87 & $-0,536$ & 0,675 & 0,69 & $0,524^{* *}$ & - & \\
\hline $\mathbf{3}$ & Yenilikçi Davranış & 3,96 & $-0,738$ & 0,400 & 0,76 & $0,429^{* *}$ & $0,440^{* *}$ & - & \\
\hline $\mathbf{4}$ & Görev Performansı & 3,48 & $-0,269$ & 0,276 & 0,83 & $0,283^{* *}$ & $0,275^{* *}$ & $0,241^{* *}$ & - \\
\hline Cronbach Alfa Güvenirlilik Katsayısı & & & & 0,864 & 0,807 & 0,834 & 0,940 \\
\hline${ }^{* *}$ p $<0.01$
\end{tabular}

\subsection{Hipotez Testleri}

Araştırma hipotezlerinin test edilmesi için çoklu doğrusal regresyon analizleri gerçekleştirilmiştir. Öz yeterliliğin ve örgütsel özdeşleşmenin bağımsız değişken olduğu yenilikçiliğin ise bağımlı değişken olduğu Model 1'de $\mathrm{H}_{1}$ ve $\mathrm{H}_{2}$ test edilmektedir. Kurulan regresyon modeli bir bütün olarak anlamlıdır $(\mathrm{F}=170,253, \mathrm{P}<0,01)$. Kurulan modeldeki bağımsız değişkenler, bağımlı değişkendeki varyansın yaklaşık \%25'ini açıklamaktadır $\left(R^{2}=0,248\right)$. Öz yeterlilik $(\beta=, 274 ; p<0,01)$ ve örgütsel özdeşleşmenin $(\beta=, 297 ; p<0,01)$ yenilikçiliği istatistiksel olarak anlamlı ve pozitif yönde etkilediği sonucuna ulaşılmıştır. Modele ilişkin regresyon analizi sonuçları Tablo 3'de görülmektedir. $\mathrm{Bu}$ sonuçlara göre $\mathrm{H}_{1}$ ve $\mathrm{H}_{2}$ hipotezleri desteklenmiştir.

Ayrıca, çoklu bağlantı probleminin olup olmadığını anlamak için VIF ve Tolerans değerlerine bakı1ır. VIF değeri 10 ve üzeri, Tolerans değeri 0,10 'dan küçük olması durumunda çoklu doğrusallığın var olduğu belirtilmektedir (Tatlıdil \& Ortunç, 2011; Gujarati, 2004). Modelde yer alan değerlere göre VIF değerleri 10 'dan küçük ve tolerans değeri ise 0,10 'dan büyüktür. Modelde yer alan değişkenler arasında çoklu doğrusallık problemi bulunmamaktadır. Diğer taraftan, çoklu doğrusal regresyon analizi için ayrıca oto-korelasyon, yani bağımsız değişkenlerin hata terimleri arası korelasyon olmaması koşulu sağlanmalıdır. Regresyon modelinde oto-korelasyon şüphesinin olup olmadığı, Durbin-Watson analizi ile sinanmaktadır. Bu değerin de istenen aralıkta olduğu görülmektedir (Durbin- Watson değeri, 0 ile 4 arası değer almakta ve 2 değeri aldığında bağımsız değişkenlerin hata terimleri arası korelasyon olmadığını göstermektedir. Durbin-Watson değeri 2'ye ne kadar yakın 
olursa, çoklu doğrusal regresyon modeli için o kadar oto-korelasyon şüphesi ortadan kalkmaktadır) (Field, 2013).

Tablo 3: Öz Yeterlilik ve Örgütsel Özdeşleşmenin Yenilikçi Davranış Üzerindeki Etkisi

\begin{tabular}{lccccc}
\hline MODEL 1 & \multicolumn{5}{c}{ Bağımlı Değišken: Yenilikçi Davranıs } \\
\hline Bağımsiz Değissenler & $\boldsymbol{\beta}$ & $\mathbf{t}$ & Sig. & Tolerans & VIF \\
\hline Öz Yeterlilik & 0,274 & 8,635 &, $000^{* *}$ & 0,725 & 1,379 \\
\hline Örgütsel Özdeşleşme & 0,297 & 9,361 &, $000^{* *}$ & 0,698 & 1,329 \\
\hline $\mathrm{R}^{2}$ & 0,248 & & & & \\
Model F & 170,253 & & & & \\
$\mathrm{p}$ & $<, 0001$ & & & & \\
Durbin-Watson & 1.688 & & &
\end{tabular}

Öz yeterlilik örgütsel özdeşleşme ve yenilikçi davranışın bağımsız değişken olduğu görev performansının bağımlı değişken olduğu Model 2'de $\mathrm{H}_{3}, \mathrm{H}_{4}$ ve $\mathrm{H}_{5}$ test edilmektedir. Kurulan regresyon modeli bir bütün olarak anlamlıdır $(\mathrm{F}=42,422, \mathrm{P}<0,01)$. Kurulan modeldeki bağımsız değişkenler, bağımlı değişkendeki varyansın yaklaşık \%11'ini açıklamaktadır $\left(\mathrm{R}^{2}=0,110\right)$. Öz yeterlilik $(\beta=, 161 ; p<0,01)$, örgütsel özdeşleşme $(\beta=, 144 ; p<0,01)$ ve yenilikçi davranışın $(\beta=, 144$; $\mathrm{p}<0,01)$ görev performansını istatistiksel olarak anlamlı ve pozitif yönde etkilediği sonucuna ulaşılmıştır. Modele ilişkin regresyon analizi sonuçları Tablo 4'de görülmektedir. Bu sonuçlara göre $\mathrm{H}_{3}, \mathrm{H}_{4}$ ve $\mathrm{H}_{5}$ hipotezleri desteklenmiştir. Ayrıca modelde yer alan değerlere göre VIF değerleri 10'dan küçük ve Tolerans değeri ise 0,10 'dan büyüktür. Yani, modelde yer alan değişkenler arasında çoklu doğrusallık problemi bulunmamaktadır. Diğer taraftan, Durbin-Watson değerinin de istenen aralıkta olduğu görülmektedir.

Tablo 4: Öz Yeterlilik, Örgütsel Özdeşleşme ve Yenilikçi Davranışın Görev Performansı Üzerindeki Etkisi

\begin{tabular}{lccccc}
\hline MODEL 2 & \multicolumn{5}{c}{ Bă̆ımlı Değişken: Görev Performansı } \\
\hline Bă̆ımsız Değişkenler & $\boldsymbol{\beta}$ & $\mathbf{t}$ & Sig. & Tolerans & VIF \\
\hline Öz Yeterlilik & 0,161 & 4,502 &, $000^{* *}$ & 0,676 & 1,478 \\
\hline Örgütsel Özdeşleşme & 0,144 & 4,024 &, $000^{* *}$ & 0,669 & 1,496 \\
\hline Yenilikçi Davranış & 0,105 & 3,090 &, $001^{* *}$ & 0,752 & 1,329 \\
\hline $\mathrm{R}^{2}$ & 0,110 & & & & \\
Model F & 42,422 & & & & \\
$\mathrm{p}$ & $<, 0001$ & & & &
\end{tabular}

\section{SONUÇ VE TARTIŞMA}

$\mathrm{Bu}$ çalışmanın amacı öz yeterlilik ve örgütsel özdeşleşmenin yenilikçi davranış ve görev performansı üzerindeki etkisini araştırmaktır. Eğitim sektöründe gerçekleştirilen bu çalışma ile değişkenlerin etkileri bir dizi hipotez ile test edilmiştir. Araştırma sonuçları hipotezleri destekler nitelikte bulunmuştur.

Çalışmanın birinci ve ikinci hipotezini kapsayan Model 1, öz yeterlilik ve örgütsel özdeşleşmenin yenilikçi davranışı pozitif yönde anlamlı şekilde etkilediği öngörüsünü desteklemiştir. Ulaşılan sonuçlar literatürdeki çalışmalarla uyumludur ve benzer düzeyde etki oranları ortaya koymuştur (Hsiao vd., 2011; Michael vd., 2011; Yu \& Chen, 2016; Ng \& Lucianetti, 2016; Mielniczuk \& Laguna, 2020; Blader \& Tyler, 2009; Xenikou, 2017). Öz yeterlilik ve örgütsel özdeşleşmenin, yenilikçi davranış üzerinde yüksek düzeyde etkisi bulunduğunu gösteren sonuçlar bu iki değişkende meydana gelecek olumlu gelişmelerin yenilikçi davranışlarda da önemli oranda olumlu etkilere yol açacağını göstermektedir. Yenilikçi davranışları arttırmak isteyen örgütlerin öncelikle öz yeterliliği yüksek ve örgüt amaçlarına hizmet edecek örgüt hedefleri ile benzer hedeflere sahip çalışanları istihdam etmeye öncelik vermelidir. Sonraki aşamalarda çalışanların öz yeterlilik algılarını yüksek tutmalarını sağlayabilmek için uygun örgüt iklimi ve yönetsel faaliyetlerle çalışanlarını desteklemesi, örgütsel özdeşleşmelerini arttırmak için örgütsel imajını, değerlerini ve uygulamalarını çalışanlarının özdeşleşme yaşamalarını sağlayacak düzeyde ve bu özdeşleşmeyi sürdürebilecekleri tutarlılıkta devam ettirmesi gerekir. Bu sebeple yöneticiler yapılan işlerin ve politikaların açıç̧a 
tanımlanmasını sağlamalı, formal ilişkilerin belirgin olduğu çalışanlar tarafından bilindiği ve kabul gördüğü örgütsel yapıyı sağlamalı ve korumalıdır. Eleştiri ve tehditten ziyade ödül ve teşvik içeren destekleyici örgüt iklimi oluşturulması, personel güçlendirme konusuda faaliyetler yapılması, çalışanlara örğüt içi yatay ve dikey hareketlilik imkanı sunulması, çalışanlara faaliyet alanlarına yönelik eğitim imkanları sunulması ve örgüt içi sosyal aktivitelerin düzenlenmesi bu hususta örgütlerin başvurabileceği faydalı uygulamalardır. Fakat buradaki esas kilit nokta öz yeterliliğine olan inancı yüksek ve örgütle uyumlu amaç ve hedeflere sahip çalışanların istihdam edilmesidir.

Çalışmanın üçüncü, dördüncü ve beşinci hipotezlerini kapsayan Model 2; öz yeterlilik, örgütsel özdeşleşme ve yenilikçi davranışın görev performansı üzerinde pozitif yönde anlamlı etkisi olduğu öngörüsünü desteklemiştir. Ulaşılan sonuçlar literatürdeki çalışmalarla uyumludur ve benzer düzeyde etki oranları ortaya koymuştur (Aryee vd., 2012; Moreira vd., 2013; Locke vd., 1982; Stajkovic \& Luthans, 1998; Tang vd., 2020; Carter vd., 2018; Liu vd., 2011; Walumbwa vd., 2011; Lu vd., 2016). Sonuçlar öz yeterlilik, örgütsel özdeşleşmenin ve yenilikçi davranışın görev performansı üzerinde yüksek düzeyde olmasa da anlamlı düzeyde etkisi bulunduğunu göstermektedir. Pozitif örgütsel davranışları ve örgütsel çıktıları arttırmak her işletmenin amaçları arasındadır. Araştırma sonuçları göstermektedir ki öz yeterlilik ve örgütsel özdeşleşmede yapılacak geliştirmeler dolayısıyla yenilikçi davranışlarda olumlu bir gelişme sağlanırken, bütünleşik olarak bu olumlu gelişmeler görev performansı üzerinde de olumlu etkiye sahip olacaktır. Yöneticilerin bu konuda öz yeterliliği yüksek örgütle uyumlu hedefleri olan çalışanları işe alarak, çalışanlarına destekleyici, bireysel sorumluluğa önem veren ve risk almayı teşvik eden iklime yönelik organizasyonel yapıyı sağlayarak ve bu yapıyı koruyarak faaliyet göstermeleri bir bütün olarak örgütsel performans1 olumlu etkileyecektir. Yenilikçilik davranışı ve görev performansının öncülü olarak görünen bu öz yeterlilik ve örgütsel özdeşleşmenin örgütün olumlu çıktıları için önemli değişkenler olduğu alandaki araştırmalarla tutarl11ık gösteren bu çalışma ile ortaya konmuştur (Riketta, 2005; Judge \& Bono, 2001).

$\mathrm{Bu}$ araştırmanın bulguları bazı sınırlılıklara sahiptir. Belirli bir sektör çalışanları arasından kolayda örnekleme yöntemiyle elde edilen veriler ile yapılan analizler sonucunda ulaşılan bulguların tüm çalışanlara genellenebilmesi mümkün değildir. Araştırmanın farklı sektörlerde, tesadüfi yöntemlerle seçilen örneklemlerde tekrarlanması daha genellenebilir sonuçlar elde edilmesini sağlayabilir. Gelecek çalışmalarda örgütlerin performans göstergelerine dayalı olarak değerlendirme yapılması gerçekleşen performansa yönelik sonuçlar elde edilmesini sağlayabilir. Ayrıca çeşitli demografik ve mesleki özelliklerin etkisinin de modellere dahil edilmesi, kamu ve özel sektör çalışanları açısından bir karşılaştırma yapılması etki oranlarında farklı sonuçlar doğurabilir.

Etik Beyanı: Bu çalışmada kullanılan anket yöntemi için Gebze Teknik Üniversitesi Etik Kurulu'ndan 28/01/2021 tarihli ve 2021/05 nolu toplantisinda 05/01 sira sayll kararl ile izin alınmıştır. Aksi bir durumun tespiti halinde AKAD Dergisinin hiçbir sorumluluğu olmayıp, tüm sorumluluk çalı̧̧manın yazar (lar) ına aittir.

Yazar Katkı Beyant:1. Yazarın katkı oranı \%30, 2. Yazarın katkı oranı ise \%40, 3. Yazarın katkı orant ise \%30'dur.

Çıkar Beyant: Yazarlar arasında çıkar çatışması yoktur.

Ethics Statement: Permission for this study was obtained from the Ethics Committee of Gebze Technic University with the decision number 05/01 at the meeting dated 28/01/2021 and numbered 2021/05 of the relevant board. In case of detection of a contrary situation, AKAD Journal has no responsibility and all responsibility belongs to the author (s) of the study.

Author Contributions Statement: 1st author's contribution rate 30\%, 2nd author's contribution rate $40 \%$, 3 rd author's contribution rate $30 \%$.

Conflict of Interest: There is no conflict of interest among the authors. 


\section{KAYNAKÇA}

Amabile, T. M., Barsade, S. G., Mueller, J. S., \& Staw, B. M. (2005). Affect and creativity at work. Administrative Science Quarterly, 50(3), 367-403. https://doi.org/10.2189/asqu.2005.50.3.367

Aryee, S., Walumbwa, F. O., Zhou, Q., \& Hartnell, C. A. (2012). Transformational leadership, innovative behavior, and task performance: Test of mediation and moderation processes. Human Performance, 25(1), 1-25. https://doi.org/10.1080/08959285.2011.631648

Ashforth, B. E., \& Mael, F. (1989). Social identity theory and the organization. Academy of Management Review, 14(1), 20-39. https://doi.org/10.5465/amr.1989.4278999

Axtell, C. M., Holman, D. J., Unsworth, K. L., Wall, T. D., Waterson, P. E., \& Harrington, E. (2000). Shopfloor innovation: Facilitating the suggestion and implementation of ideas. Journal of Occupational and Organizational Psychology, 73(3), 265-285. https://doi.org/10.1348/096317900167029

Bandura, A. (1977). Self-efficacy: Toward a unifying theory of behavioral change. Psychological Review, 84(2), 191-215. https://psycnet.apa.org/doi/10.1037/0033-295X.84.2.191

Bandura, A. (1982). Self-efficacy mechanism in human agency. American Psychologist, 37(2), 122147. https://psycnet.apa.org/doi/10.1037/0003-066X.37.2.122

Bandura, A. (1995). Self-efficacy in changing societies. Cambridge University Press.

Bandura, A. (1997). Self-efficacy: The exercise of control. W. H. Freeman.

Bani-Melhem, S., Zeffane, R., \& Albaity, M. (2018). Determinants of employees' innovative behavior. International Journal of Contemporary Hospitality Management, 30(3), 1601-1620. https://doi.org/10.1108/IJCHM-02-2017-0079

Barling, J., \& Abel, M. (1983). Self-efficacy beliefs and tennis performance. Cognitive Therapy and Research, $7(3)$

265-272. http://scholar.google.com.tr/scholar url?url=https\%3A\%2F\%2Flink.springer.com\%2Fcontent\% 2Fpdf\%2F10.1007\%2FBF01205140.pdf\&hl=tr\&sa=T\&ct=res\&cd=0\&d=774478577149083446 \&ei=dK00YIiFL92Gy9YPmIS36Ac\&scisig=AAGBfm1G vRgjLLyOPHztXfuG4bBELJqjA\&n ossl=1\&ws=1920x921\&at=Self-efficacy\%20beliefs\%20and\%20tennis\%20performance

Befort, N., \& Hattrup, K. (2003). Valuing task and contextual performance: Experience, job roles, and ratings of the importance of job behaviors. Applied HRM Research, 8(1), 17-32. http://citeseerx.ist.psu.edu/viewdoc/download?doi=10.1.1.471.9915\&rep=rep1\&type=pdf

Blader, S. L., \& Tyler, T. R. (2009). Testing and extending the group engagement model: Linkages between social identity, procedural justice, economic outcomes, and extrarole behavior. Journal of Applied Psychology, 94, 445-464. https://psycnet.apa.org/doi/10.1037/a0013935

Borman, W. C., \& Motowidlo, S. J. (1997). Task performance and contextual performance: The meaning for personnel selection research. Human Performance, 10(2), 99-109. https://doi.org/10.1207/s15327043hup1002 3

Carmeli, A., Gilat, G., \& Waldman, D. A. (2007). The role of perceived organizational performance in organizational identification, adjustment and job performance. Journal of Management Studies, 44(6), 972-992. https://doi.org/10.1111/j.1467-6486.2007.00691.x

Carrizo Moreira, A., \& Silva, P. M. (2013). Market orientation, innovation and organizational

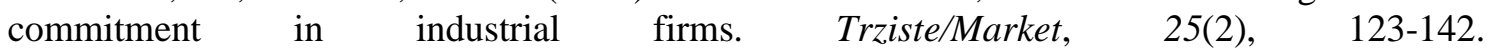
http://eds.b.ebscohost.com/eds/pdfviewer/pdfviewer?vid=0\&sid=0dd27915-d6e7-42f4-85c0a2c85411f5ae\%40pdc-v-sessmgr03

Carter, W. R., Nesbit, P. L., Badham, R. J., Parker, S. K., \& Sung, L. K. (2018). The effects of employee engagement and self-efficacy on job performance: A longitudinal field study. The International Journal of Human Resource Management, 29(17), 2483-2502. https://doi.org/10.1080/09585192.2016.1244096 
Chen, G., Gully, S. M., \& Eden, D. (2001). Validation of a new general self-efficacy scale. Organizational Research Methods, 4(1), 62-83. https://doi.org/10.1177\%2F109442810141004

Chen, T., Li, F., \& Leung, K. (2016). When does supervisor support encourage innovative behavior? Opposite moderating effects of general self-efficacy and internal locus of control. Personnel Psychology, 69(1), 123-158. https://doi.org/10.1111/peps.12104

Christ, O., Van Dick, R., Wagner, U., \& Stellmacher, J. (2003). When teachers go the extra mile: Foci of organisational identification as determinants of different forms of organisational citizenship behaviour among schoolteachers. British Journal of Educational Psychology, 73(3), 329-341. https://doi.org/10.1348/000709903322275867

Cieslak, R., Benight, C. C., Rogala, A., Smoktunowicz, E., Kowalska, M., Katarzyna Zukowska, K., Yeager, C., \& Luszczynska, A. (2016). Effects of internet-based self-efficacy intervention on secondary traumatic stress and secondary posttraumatic growth among health and human services professionals exposed to indirect trauma. Frontiers in Psychology, 4(7), 1-13. https://doi.org/10.3389/fpsyg.2016.01009

Dirani, K. M. (2009). Measuring the learning organization culture, organizational commitment and job satisfaction in the Lebanese banking sector. Human Resource Development International, 12(2), 189-208. https://doi.org/10.1080/13678860902764118

Dutton, J. E., Dukerich, J. M., \& Harquail, C. V. (1994). Organizational images and member identification. Administrative Science Quarterly, 39, 239-263. https://www.jstor.org/stable/pdf/2393235.pdf

Eisenberger, R., Fasolo, P., \& Davis-LaMastro, V. (1990). Perceived organizational support and employee diligence, commitment, and innovation. Journal of Applied Psychology, 75(1), 51-59. https://psycnet.apa.org/doi/10.1037/0021-9010.75.1.51

Evers, W. J., Brouwers, A., \& Tomic, W. (2002). Burnout and self-efficacy: A study on teachers' beliefs when implementing an innovative educational system in the Netherlands. British Journal of Educational Psychology, 72(2), 227-243. https://doi.org/10.1348/000709902158865

Fattah, A. H. (2017). The effect of organizational culture, leader behavior, self-efficacy, and job satisfaction on job performance of the employees. Jurnal Terapan Manajemen dan Bisnis, 3(2), 102-110. https://core.ac.uk/download/pdf/231283799.pdf

Field, A. (2013). Discovering statistics using IBM SPSS Statistics (4th ed.). Sage.

Floyd, F. J., \& Widaman, K. F. (1995). Factor analysis in the development and refinement of clinical assessment instruments. Psychological Assessment, 7(3), 286-299. https://psycnet.apa.org/doi/10.1037/1040-3590.7.3.286

Fuchs, C., Sting, F. J., Schlickel, M., \& Alexy, O. (2019). The ideator's bias: How identity-induced self-efficacy drives overestimation in employee-driven process innovation. Academy of Management Journal, 62(5), 1498-1522. https://doi.org/10.5465/amj.2017.0438

Gautam, T., Van Dick, R., \& Wagner, U. (2004). Organizational identification and organizational commitment: Distinct aspects of two related concepts. Asian Journal of Social Psychology, 7(3), 301-315. https://doi.org/10.1111/j.1467-839X.2004.00150.x

Gebze Milli $\quad$ Eğitim $\quad$ Müdürlüğ̈ü. (2019). Saylsal $\quad$ bilgiler.
http://gebze.meb.gov.tr/meb_iys_dosyalar/2019_03/15111532_2018.2019_sayYsal_bilgiler_2.p
$\underline{\text { df. }}$

Gilson, L. L., Mathieu, J. E., Shalley, C. E., \& Ruddy, T. M. (2005). Creativity and standardization: Complementary or conflicting drivers of team effectiveness? Academy of Management Journal, 48(3), 521-531. https://doi.org/10.5465/amj.2005.17407916

Gong, Y., Huang, J. C., \& Farh, J. L. (2009). Employee learning orientation, transformational leadership, and employee creativity: The mediating role of employee creative self-efficacy. Academy of Management Journal, 52(4), 765-778. https://doi.org/10.5465/amj.2009.43670890 
Goodman, S. A., \& Svyantek, D. J. (1999). Person-organization fit and contextual performance: Do shared values matter. Journal of Vocational Behavior, 55(2), 254-275. https://doi.org/10.1006/jvbe.1998.1682

Greenhalgh, T., Robert, G., Macfarlane, F., Bate, P., Kyriakidou, O., \& Peacock, R. (2005). Storylines of research in diffusion of innovation: A meta-narrative approach to systematic review. Social Science \& Medicine, 61(2), 417-430. https://doi.org/10.1016/j.socscimed.2004.12.001

Gujarati, D. N. (2004). Basic econometrics (4th ed.). The McGraw-Hill Companies.

Hall, D. T., \& Schneider, B. (1972). Correlates of organizational identification as a function of career pattern and organizational type. Administrative Science Quarterly, 17, 340-350. https://doi.org/10.5465/ambpp.1972.4981421

Hall, D. T., Schneider, B., \& Nygren, H. T. (1970). Personal factors in organizational identification. Administrative Science Quarterly, 15(2), 176-190. https://www.jstor.org/stable/pdf/2391488.pdf

He, H., \& Brown, A. D. (2013). Organizational identity and organizational identification: A review of the literature and suggestions for future research. Group \& Organization Management, 38(1), 335. https://doi.org/10.1177\%2F1059601112473815

Hsiao, H. C., Tu, Y. L., Chang, J. C., \& Chen, S. C. (2011). The influence of teachers' self-efficacy on innovative work behavior. International Conference on Social Science and Humanity, 5(1), 233-237. https://www.researchgate.net/publication/268405600

Huy, Q. N. (1999). Emotional capability, emotional intelligence, and radical change. Academy of Management Review, 24(2), 325-345. https://doi.org/10.5465/amr.1999.1893939

Janssen, O. (2003). Innovative behaviour and job involvement at the price of conflict and less satisfactory relations with co-workers. Journal of Occupational and Organizational Psychology, 76(3), 347-364. https://doi.org/10.1348/096317903769647210

Janssen, O., \& Van Yperen, N.W. (2004). Employees' goal orientations, the quality of leader-member exchange, and the outcomes of job performance and job satisfaction. Academy of Management Journal, 47(3), 368-384. https://doi.org/10.5465/20159587

Jawahar, I. M., \& Carr, D._(2007). Conscientiousness and contextual performance: The compensatory effects of perceived organizational support and leader-member exchange. Journal of Managerial Psychology, 22(4), 330-349. https://doi.org/10.1108/02683940710745923

Judge, T. A., \& Bono, J. E. (2001). Relationship of core self-evaluation traits-self-esteem, generalized self efficacy, locus of control, and emotional stability-with job-satisfaction and performance: A meta-analysis. Journal of Applied Psychology, 86, 80-92. https://psycnet.apa.org/buy/2001$\underline{16970-007}$

Kim, M. S., \& Koo, D. W. (2017). Linking LMX, engagement, innovative behavior, and job performance in hotel employees. International Journal of Contemporary Hospitality Management, 29(12), 3044-3062. https://doi.org/10.1108/IJCHM-06-2016-0319

Lee, S. M. (1971). An empirical analysis of organizational identification. Academy of Management Journal, 14, 213-226. https://doi.org/10.5465/255308

Li, J. J., Wong, I. A., \& Kim, W. G. (2016). Effects of psychological contract breach on attitudes and performance: The moderating role of competitive climate. International Journal of Hospitality Management, 55, 1-10. https://doi.org/10.1016/j.ijhm.2016.02.010

Liu, C., Marchewka, J. T., Lu, J., \& Yu, C. S. (2005). Beyond concern-a privacy-trust-behavioral intention model of electronic commerce. Information \& Management, 42(2), 289-304. https://doi.org/10.1016/j.im.2004.01.003

Liu, W., He, C., Jiang, Y., Ji, R., \& Zhai, X. (2020). Effect of gig workers' psychological contract fulfillment on their task performance in a sharing economy-A perspective from the mediation of organizational identification and the moderation of length of service. International Journal of 
Environmental Research and Public Health, 17(7), 1-20. https://doi.org/10.3390/ijerph17072208

Liu, Y., Loi, R., \& Lam, L. W. (2011). Linking organizational identification and employee performance in teams: The moderating role of team-member exchange. The International Journal of Human Resource Management, 22(15), 3187-3201. https://doi.org/10.1080/09585192.2011.560875

Locke, E. A., Fredrick, E., Bobko, P., \& Lee, C. (1984). Effect of self-efficacy, goals, and task strategies on task performances. Journal of Applied Psychology, 69, 241-251. https://psycnet.apa.org/doi/10.1037/0021-9010.69.2.241

Lu, V. N., Capezio, A., Restubog, S. L. D., Garcia, P. R., \& Wang, L. (2016). In pursuit of service excellence: Investigating the role of psychological contracts and organizational identification of frontline hotel employees. Tourism Management, 56, 8-19. https://doi.org/10.1016/j.tourman.2016.03.020

Luszczynska, A., Gutiérrez-Doña, B., \& Schwarzer, R. (2005). General self-efficacy in various domains of human functioning: Evidence from five countries. International Journal of Psychology, 40(2), 80-89. https://doi.org/10.1080/00207590444000041

Mael, F., \& Ashforth, B. E. (1992). Alumni and their alma mater: A partial test of the reformulated model of organizational identification. Journal of Organizational Behavior, 13(2), 103-123. https://doi.org/10.1002/job.4030130202

Markus, H., \& Wurf, E. (1987). The dynamic self-concept: A social psychological perspective. Annual $\begin{array}{lllll}\text { Review of } & \text { Psychology, 299-337. }\end{array}$ https://www.annualreviews.org/doi/pdf/10.1146/annurev.ps.38.020187.001503

Michael, L. H., Hou, S. T., \& Fan, H. L. (2011). Creative self-efficacy and innovative behavior in a service setting: Optimism as a moderator. The Journal of Creative Behavior, 45(4), 258-272. https://doi.org/10.1002/j.2162-6057.2011.tb01430.x

Mielniczuk, E., \& Laguna, M. (2020). Positive affect mediates the relationship between self-efficacy and innovative behavior in entrepreneurs. The Journal of Creative Behavior, 54(2), 267-278. https://doi.org/10.1002/jocb.364

Miller, V. D., Allen, M., Casey, M. K., \& Johnson, J. R. (2000). Reconsidering the organizational identification questionnaire. Management Communication Quarterly, 13(4), 626-658. https://doi.org/10.1177\%2F0893318900134003

Newman, A., Obschonka, M., Schwarz, S., Cohen, M., \& Nielsen, I. (2019). Entrepreneurial selfefficacy: A systematic review of the literature on its theoretical foundations, measurement, antecedents, and outcomes, and an agenda for future research. Journal of Vocational Behavior, 110, 403-419. https://doi.org/10.1016/j.jvb.2018.05.012

Ng, T. W. H., \& Lucianetti, L. (2016). Within-individual increases in innovative behavior and creative, persuasion, and change self-efficacy over time: A social-cognitive theory perspective. Journal of Applied Psychology, 101(1), 14-34. https://psycnet.apa.org/doi/10.1037/apl0000029

Omri, W. (2015). Innovative behavior and venture performance of SMEs. European Journal of Innovation Management, 18(2), 195-217. https://doi.org/10.1108/EJIM-02-2013-0015

Peng, X., Lee, S., \& Lu, Z. (2020). Employees' perceived job performance, organizational identification, and pro-environmental behaviors in the hotel industry. International Journal of Hospitality Management, 90, 102632. https://doi.org/10.1016/j.ijhm.2020.102632

Pirola-Merlo, A., \& Mann, L. (2004). The relationship between individual creativity and team creativity: Aggregating across people and time. Journal of Organizational Behavior, 25(2), 235257. https://doi.org/10.1002/job.240 
Riaz, S., Xu, Y., \& Hussain, S. (2018). Understanding employee innovative behavior and thriving at work: A Chinese perspective. Administrative Sciences, 8(3), 46-60. https://doi.org/10.3390/admsci8030046

Riketta, M. (2005). Organizational identification: A meta-analysis. Journal of Vocational Behavior, 66, 358-384. https://doi.org/10.1016/j.jvb.2004.05.005

Scott, S. G., \& Bruce, R. A. (1994). Determinants of innovative behavior: A path model of individual innovation in the workplace. Academy of Management Journal, 37(3), 580-607. https://doi.org/10.5465/256701

Seligman, M. E. P., \& Csikszentmihalyi, M. (2000). Positive psychology: An introduction. American Psychologist, 55(1), 5-14. https://psycnet.apa.org/doi/10.1037/0003-066X.55.1.5

Stajkovic, A. D., \& Luthans, F. (1998). Self-efficacy and work-related performance: A meta-analysis. Psychological Bulletin, 124(2), 240-261. https://psycnet.apa.org/doi/10.1037/0033$\underline{2909.124 .2 .240}$

Suliman, A. M. (2001). Work performance: Is it one thing or many things? The multidimensionality of performance in a Middle Eastern context. International Journal of Human Resource Management, 12(6), 1049-1061. https://www.tandfonline.com/doi/abs/10.1080/713769689

Sverke, M., Låstad, L., Hellgren, J., Richter, A., \& Näswall, K. (2019). A meta-analysis of job insecurity and employee performance: Testing temporal aspects, rating source, welfare regime, and union density as moderators. International Journal of Environmental Research and Public Health, 16(14), 1-29. https://doi.org/10.3390/ijerph16142536

Tabachnick, B. G., \& Fidell, L. S. (2007). Using multivariate statistics. MA: Pearson.

Tang, H., Wang, G., Zheng, J., Luo, L., \& Wu, G. (2020). How does the emotional intelligence of project managers affect employees' innovative behaviors and job performance? The moderating role of social network structure hole. SAGE Open, 10(4), 1-15. https://doi.org/10.1177\%2F2158244020969382

Tatlıdil, H., \& Ortunç, B. (2011). Kredi temerrüt swaplarının fiyatlama yöntemleri ve fiyatlamayı etkileyen finansal göstergelerin regresyon ve panel veri analizleri ile belirlenmesi. Bankacılar Dergisi, 77, 25-43. https://www.tbb.org.tr/Dosyalar/Dergiler/Dokumanlar/Dergi77.pdf

Teng, C. C., Hu, C. M., \& Chang, J. H. (2019). Triggering creative self-efficacy to increase employee innovation behavior in the hospitality workplace. The Journal of Creative Behavior, 54(4), 912 925. https://doi.org/10.1002/jocb.419

Thurlings, M., Evers, A. T., \& Vermeulen, M. (2015). Toward a model of explaining teachers' innovative behavior: A literature review. Review of Educational Research, 85(3), 430-471. https://doi.org/10.3102\%2F0034654314557949

Van Knippenberg, D., \& Van Schie, E. C. (2000). Foci and correlates of organizational identification. Journal of Occupational and Organizational Psychology, 73(2), 137-147. https://doi.org/10.1348/096317900166949

Walumbwa, F. O., Cropanzano, R., \& Hartnell, C. A. (2009). Organizational justice, voluntary learning behavior, and job performance: A test of the mediating effects of identification and leader-member exchange. Journal of Organizational Behavior, 30(8), 1103-1126. https://doi.org/10.1002/job.611

Walumbwa, F. O., Mayer, D. M., Wang, P., Wang, H., Workman, K., \& Christensen, A. L. (2011). Linking ethical leadership to employee performance: The roles of leader-member exchange, self-efficacy, and organizational identification. Organizational Behavior and Human Decision Processes, 115(2), 204-213. https://doi.org/10.1016/j.obhdp.2010.11.002

West, M. A. (2002). Sparkling fountains or stagnant ponds: An integrative model of creativity and innovation implementation in work groups. Applied Psychology, 51(3), 355-387. https://doi.org/10.1111/1464-0597.00951 
Woodman, R. W., Sawyer, J. E., \& Griffin, R. W. (1993). Toward a theory of organizational creativity. Academy of Management Review, 18(2), 293-321. https://doi.org/10.5465/amr.1993.3997517

Xenikou, A. (2017). Transformational leadership, transactional contingent reward, and organizational identification: The mediating effect of perceived innovation and goal culture orientations. Frontiers in Psychology, 8, 1754. https://doi.org/10.3389/fpsyg.2017.01754

Yu, J., \& Chen, S. (2016). Gender moderates firms' innovation performance and entrepreneurs' selfefficacy and risk propensity. Social Behavior and Personality: An International Journal, 44, 679-691. https://doi.org/10.2224/sbp.2016.44.4.679

Yuan, F., \& Woodman, R. W. (2010). Innovative behavior in the workplace: The role of performance and image outcome expectations. Academy of Management Journal, 53(2), 323-342. https://doi.org/10.5465/amj.2010.49388995 